\title{
Green Accounting: A Management Strategy and Corporate Social Responsibility Implementation
}

\section{Gusti Ayu Purnamawati ${ }^{*}$, Gede Adi Yuniarta², I Putu Gede Diatmika ${ }^{3}$,}

1,2,3 Economic Faculty, Universitas Pendidikan Ganesha

\section{A R T I C L E I N F O}

Article history:

Received 15 March 2018

Received in revised form

10 May 2018

Accepted 30 June2018

Available online 28 August

2018

Keywords:

Financial Statement; Green

Accounting; Environmental
A B S T R A C T

This activity aims to know the implementation of Green Accounting As Management Strategy and Form of Social Responsibility Implementation at the Village Owned Enterprises in Buleleng Regency (BUMDes). This descriptive quantitative research was carried out with the purpose of mapping the academic works published on the environmental accounting and environmental costs areas and, fundamentally, describing the type of study (creation of a model or descriptive study) and the type of strategy (case study or non-identified). The sample is the managers of BUMDes which amounted to 10 people. With the application of environmental accounting in all operational activities and directly oriented to the interests of profit, people (community) and the planet (environmental sustainability). The results show that: $90 \%$ of the level of achievement that Bumdes managers have been able to apply environmental accounting properly.

\footnotetext{
${ }^{*}$ Corresponding author.

E-mail addresses: ayupurnama07@yahoo.com (I Gusti Ayu Purnamawati)
} 


\section{Introduction}

Environmental problems in Indonesia are important factors to be considered given the impact of poor environmental management. The issue of environmental damage, its causes and impact on human life in the present as well as future impacts caused the entire community to realize the importance of preserving the environment. The modern economy, as it is today, has raised environmental issues such as global warming, eco-efficiency and other industrial activities that have a direct impact on the surrounding environment (Agustia, 2010). Many countries around the world have mandated enterprises to establish green accounting and to disclose environmental information for the reference of interested parties ( $\mathrm{Tu} \&$ Huang, 2015). The notion of corporate social responsibility (CSR) is nowadays related to issues such as environmental protection, health and safety at work, relations with local communities and relations with consumers. It may be defi ned as a concept whereby companies decide voluntarily to contribute to a better society and a cleaner environment (European Commission, 2001). Companies are thus supposed to voluntarily integrate social and environmental concerns in their operations and interaction with stakeholders (Branco \& Delgado, 2009). Although green accounting has become a norm around the world, it is still in the promotion stage in many countries (Tu \& Huang, 2015).

Village Owned Enterprises (BUMDes) as one of the company's organizations, is expected to show their social responsibility by reporting related to efforts to prevent environmental pollution, by applying environmental accounting. Therefore, it will automatically provide a boost for BUMDes to preserve the environment. Disclosure of environmental accounting in developing countries is still very lacking. BUMDes in the field of environment becomes the main focus related to the government program in improving the productive economy while maintaining the environment. Such BUMDes can be encountered like an Integrated Waste Management Site (TPST) which seeks to empower waste to be useful for the community and village.

Buleleng Regency is located in the northern part of Bali island. In Buleleng regency itself there are two villages that have BUMDes whose business units have TPST, namely BUMDES Tajun Village and BUMDES Village Bengkala, Kubutambahan Subdistrict. In Kabupaten Buleleng, there are 23 TPSTs in 9 sub-districts, including Tejakula, Kubutambahan, Sawan, Buleleng, Busungbiu, Sukasada, Seririt, Gerokgak and Banjar. In Kubutambahan sub-district there are 3 TPSTs in Kubutambahan Village (TPST Teguh Karya built in 2009), Tajun Village (TPST Mandala Giri Amerta built in 2013), and Bengkala Village (Valli Karya Lestari TPST built in 2013). Tajun Village has owned BUMDes since 2011. The name of BUMDes is Mandala Giri Amertha. BUMDes Mandala Giri Amertha is one of the BUMDes that operates in four operational areas namely Village Facility Management Unit, Integrated Waste Management Unit, Savings and Loan Unit and Market Management Unit. BUMDes Mandala Giri Amertha in its operation unit is not only aiming to find profit only, but there is one business unit that focuses on the environmental health of the village through one of business unit that is formed of TPST Mandala Giri Amertha.

Tajun Village is one of 13 villages in Kubutambahan sub-district, Buleleng regency, Bali province. The location of the village is very cool that is in the hilly area with many existing plantations. The population of the village of Tajun early 2015 is about 1800 families or 6815 souls with details of the number of men as much as 3228 souls and the number of women as much as 3161 souls. When viewed in terms of livelihood of Tajun Village residents mostly as Farmers, although there are some as civil servants, Private and Sword Officers, and some also have Household Industries such as Bamboo Woven, making cakes in accordance with the ability possessed.

The TPST Unit is the unit with the greatest contribution to the welfare of the Tajun villagers who have been established for 4 years. The name of TPST itself is TPST Mandala Giri Amerta which take shelter in the management of organic waste to be composted. The beginning of establishment of Mandala Giri Amertha TPST get full support from local government. This can be seen from the operating tools that initially received assistance from the local government.

BUMDes Tajun Village, especially in terms of handling waste into the spotlight is very interesting to be studied, because it deals with the increasingly widespread garbage issues discussed. Waste generation in mountainous areas is different from the waste generation in coastal areas. Mountainous areas are generally dominated by agriculture or plantations such as in Tajun Village, so that the waste generation is higher compared to other areas. Many efforts and innovations made by the government to reduce the volume of increasing amount of waste.

The formation of TPST is expected to be one of the solutions. TPST Mandala Giri Amertha Tajun Village has been able to show optimal performance in terms of handling organic waste to serve as compost and non-organic waste sold for the welfare of its citizens. TPST Mandiri Giri Amertha moves very well, the garbage in the village is sorted and empowered to improve the economy of the citizens. The existence of TPST Mandiri Giri Amertha become the driving force of Tajun Village community to start 
healthy life by paying attention to the cleanliness of the environment while improving the village economy. This proves that the village of Tajun became one of the villages in Buleleng that is able to change the condition of the village to be very clean, comfortable and beautiful with the level of pollution by the waste is very minimal. This success can not be separated from the commitment of Tajun Village and Village Head to continue to improve the village through the solution of rural waste management.

BUMDes as one of the company's organizations, is expected to show its social responsibility or Coporate Social Responsibility (CSR) by reporting related to the effort to prevent environmental pollution by applying environmental accounting. Therefore, it will automatically provide a boost for BUMDes to preserve the environment, one of them by applying environmental accounting.

Disclosure of environmental accounting in developing countries is still very lacking. Much of the research that has evolved in the area of Social Accounting Disclosure shows that the company reports its environmental performance is still very limited. (Lindrianasari, 2007) asserted that one of the limiting factors is the weakness of legal sanction prevailing in the country. (Lindrianasari, 2007) finds that there is a negative relationship between legal sanction of compulsory environmental disclosure with regulatory discrimination by the company. Environmental accounting also describes efforts to combine environmental benefits and costs into economic decision-making.

Accounting imposes an array of challenges of measurement informative order, recognition and valuation of environmental nature that commune with the interests of the several segments aforementioned. In order to confirm this, it is necessary to count on accurate information about the environmental costs needed to elaborate reliable financial environmental indicators (Grzebieluckas \& Campos, 2012). In accordance with the Financial Accounting Standards, accounting serves to provide information in decision making and accountability. So far, the preparation of financial statements only focused on the interests of investors and creditors, but ignore the externalities of the operations carried out, such as air pollution, water pollution, soil pollution and others (Suaryana, 2011). With the existence of environmental accounting, it is expected the organization or company more discipline in managing waste from operational results that may endanger the environment (Elyafei, 2012). However, authors from other countries, many of which from developing countries, hitherto under-represented within the research establishment, enter the ranks of contributors to Accounting, Auditing and Accountability Journal (AAAJ) and other leading edge journals (Owen, 2008). One of the great contributions in the field of social and environmental accounting internationally was granted by (Mathews, 1997), who revised 25 years of the literature in the area. The author provides a structure that allows readers and researchers to organize in time and determine the trends, offering bibliographic details from the beginning and interest for the study of this area (Grzebieluckas \& Campos, 2012).

Green accounting makes environmental expenditure a part of operational cost; thus, new thinking should be adopted for product design, in order to maintain the existing profits, enhance environmental performance or meet the green accounting rules. The new product design concept should meet the environmental requirements on product development and production (Roozenburg \& Eekels, 1995). Green accounting involves saving resources, green products, clean production and environmental production. This study explored the drivers behind the cost units and found that each factor contributes to the additional production or operational cost. (Ding, 2009) investigated Taiwanese enterprises that have been certified with ISO14000 for environmental management from the financial aspect. For the 108 samples, their environmental performances had significant negative effects on the return on assets, return on equity and net operating profit.

Environmental accounting is the field of accounting science that serves to identify, measure, assess, and report environmental accounting. Waste management undertaken requires measurement, assessment, disclosure and reporting of waste management costs from the results of the operations of the company. Application of environmental accounting also aims to find out how much environmental costs incurred in managing the waste by using the accounting system so as to minimize the costs incurred, can control the company's responsibility in maintaining the environment around the company, and can create environmental cost report to be a management guideline in decision making. Research by (Negash, 2009), the study finds that the Global Reporting Initiative's (GRI) guidelines and private sector self-regulation are insufficient to monitor environmental disclosure. The paper proposes a mandated separate statement of environmental assets and liabilities. The elements of the proposed statement are discussed. In this community service program will further examine the application of environmental accounting in the village enterprise sector. In realizing its main vision, BUMDes must always cause problems due to operational activities. Such as TPST unit in BUMDes Tajun Village is processing organic waste to be used as compost for the welfare of local people. Of course, waste waste in the form of non-organic waste that is not processed, such as glass, plastic, and other non-organic materials that require future handling. Good handling in the form of transportation for sale, or burned. Likewise, if burned, will emit the impact of 
pollution on the social environment and ultimately demand the company in this case BUMDes to issue a policy in overcome by reporting related to the effort to prevent environmental pollution, namely by applying environmental accounting.

Environmental management in business has evolved over time with a better understanding of the financial environment, costs and benefits as inputs for conventional management accounting. The main stimulus is on environment-related factors that can increase profitability and firm financial position (Seetharaman, Ismail, \& Saravanan, 2007). Accounting, as a science, has grown steadily and significantly in recent years due to the increase in the number of strictu sensu graduate programs in the theme and, consequently, in the scientific production. Environmental accounting is a branch of the accounting science (Yakhou \& Dorweiler, 2004). Environmental accounting is used to assess the full environmental costs associated with production activities and products, processes, inputs in the form of raw materials, energy, water, and output in the form of pollution products, waste water, and soil waste. Environmental accounting can also be used to track the environmental performance of an organization to be more measurable. Excellence in principle finds ways in pollution prevention with environmental management systems in environmental decision-making processes. It is necessary as a tool to measure and evaluate the benefits to be gained from business and environmental activities. Environmental management is required to quantify and identify the environmental cost impacts generated in all relevant processes such as waste disposal. Companies need to identify potential environmental impacts and their impacts in each process and evaluate managerial resources appropriately allocated for environmental influences (Seetharaman et al., 2007).

Research by (Olatunji, 2017), Results showed a per capita annual cost of 25USD resulting to over $2,824,408.125$ USD as the lost value or depreciation of biodiversity in the study area. This depreciation cost is tremendous requiring urgent attention to conservation. It was concluded that the emergence of environmental accounting tools has significant consequence on biodiversity preservation because what is counted is what is valued and what is valued is what is treasured. This calls for policy and stringent action towards conservation of forest resources. Research by (Correa \& Larrinaga, 2015), this study shows a promising cross-fertilization between interpretive insight and critical enlightenment in engagement research. The paper also explores in more depth three methodological issues: what is specific about engagement research, particularly compared to stakeholder engagement; that the decision about the locus of engagement research does not seem to be driven by the characteristics of organizations, but by the potential insight and enlightenment that the empirical setting can yield; and, finally, that engagement research requires more space for reflexivity. Research by (Aniela, 2012) on the Role of Environmental Accounting in Improving Environmental and Financial Performance The application of green accounting has a positive impact on the financial performance of the company, which is increasing the positive perception of the consumer which ended in the increase of sales and profit of the company. In addition, the application of green accounting also has an impact on improving environmental performance both in the environmental health dimension and in the environment vitality. (Nilasari, 2014) Analysis of Application of Environmental Accounting on PG Waste Management Djatiroto. The Company has classified environmental costs in terms of waste management and has carried out the environmental cost accounting treatment stages. (Hidayatullah, 2015) Analysis of Application of Environmental Accounting To Know The Process Of Waste Management And Social Responsibility At IBNU Hospital SINA Gresik City. Hospitals in measuring environmental costs in terms of operational costs of waste treatment, amounting to kos issued or called the acquisition price that refers to the realization of last year (Historical Cost). The presentation together with similar costs in the financial statements. And the disclosure goes into the notes to the hospital's financial statements.

In the main operational BUMDes Tajun TPST many cause environmental problems so that need handling and related costs such handling. The BUMDes financial reporting system is interesting to review if it is associated with the classification of costs during operation, especially in the Tajun Village BUMDes engaged in integrated waste processing, which of course there is an impact to the surrounding community or the environment. Based on the identification of the problem, then the main problem to be looked for in this community service solution is: "how do I improve the knowledge and skills of BUMDES managers in Buleleng District in the Preparation of Green Accounting as a Management Strategy and Form of Social Responsibility?". Through this training and assistance, it is expected that BUMDES managers in Buleleng Regency can make an accounting-based financial report as a form of Corporate Social Responsibility.

\section{Methods}

This descriptive quantitative research was carried out with the purpose of mapping the academic works published on the environmental accounting and environmental costs areas and, fundamentally, 
describing the type of study (theoretical dissertation, creation of a model or descriptive study) and the type of strategy (case study or non-identified) (Grzebieluckas \& Campos, 2012). Based on the identification of problems that have been done in the location of this program plan will be implemented, the conclusion that there is a set of problems currently faced by the managers of BUMDes, namely: (1) most of the managers BUMDes not yet able to calculate and create an environment-based financial report used as accountability for environmental management and corporate social responsibility, (2) BUMDes managers often have difficulties in understanding environmental accounting, so they are unaware of their application in the financial statements. One alternative that is seen as visible enough to be done is to carry out training and assistance in preparing the environmental-based financial statements as management strategies and the form of Corporate Social Responsibility (CSR). Through this training, it is expected that BUMDes managers can create environmental based financial report as a form of corporate social responsibility (CSR) and environmental management strategy.

Training and mentoring of BUMDes management in Buleleng District in applying environmental accounting and preparing financial report will start with field orientation, followed by problem identification, literature study, and operationalization of activities. Field orientation and problem identification is a way to better recognize the problems faced by BUMDes managers in Buleleng District, so from there can be found alternative solutions to the problem. The next activity is to find a solution to the problems experienced by the managers of BUMDes in Buleleng Regency through literature study. Last is the implementation of the program as agreed. To facilitate the training, the managers of BUMDes will be formed a group that will get a training package with activity material.

The strategic target audience in this activity is the managers of BUMDes in Kecamatan Kubutambahan Buleleng which amounted to 10 people. With the application of environmental accounting in all operational activities in the BUMDes then directly oriented to the interests of 3P ie profit, people (community) and the planet (environmental sustainability).

In accordance with the focus of the problem and the purpose of this activity, the method used is the method of training and programmed assistance with a group system that is terminal. This means that to train the manager of BUMDes, will be a training program and assistance scheduled. The training and facilitation will use a group system, where each business group will be given a package of training and facilitation programs conducted democratically, beginning with the introduction of knowledge and skills on environmental-based financial reports, then proceed with the practice of directly making financial statements

The materials provided during the training include: (1) the importance of bookkeeping and the benefits of its use in running the business; (2) how to prepare an environment-based financial report using applicable principles; (3) disclosure Environmental accounting as a form of accountability of CSR implementation and strategy management of the environment. In this training and mentoring activity, BUMDes managers in Buleleng District will be involved collaboratively from the beginning to the end of the activity. BUMDes managers will be involved in program planning, scheduling activities, participating in training up to the training product trial stage. To test the product the results of this training will be conducted on all types of businesses that get training and mentoring.

\section{Results and Discussion}

Record of financing to manage waste discharged from the production of the remaining production of a business is allocated in a certain stage each stage requires a cost that can be accounted for, and the stages of recording it can be done before the accounting period runs in accordance with the production process of the company. Grouping in the environmental analysis phase include:

1. Identify

The first time a company wants to determine the cost of managing the external cost of mitigation that may occur in its business operations is by identifying those impacts.

2. Recognition

Those elements that have been identified are further recognized as accounts and referred to as fees upon receipt of benefits from the amounts that have been incurred for the financing of the environment.

3. Measurement

Measurement of the value and amount of costs to be issued can be done by referring to the realization of expenses incurred in the previous period, so that will get the right amount and value according to the real needs of each period.

4. Presentation

The presentation of these environmental costs in the financial statements can be done under different 
account names because there is no standard provision for the account name that contains the allocation of the company's environmental financing.

5. Disclosure

Entities may also present separately from financial statements, environmental reports and value added statements, particularly for industries where environmental factors play an important role and for industries that consider employees to be an important reporting user group.

BUMDes performs environmental accounting stages ranging from identification of costs associated with the management of organic waste and non-organic waste, labor costs and operating machinery maintenance costs in terms of preserving the environment. Then proceed with the recognition stage, the expense is recognized in the income statement as a deterrent to the future economic value of the asset or the increase in the liabilities that have occurred and can be measured. The next step is to make measurements, BUMDes measure and assess costs incurred using the monetary unit of rupiah with reference to the realization of the cost in the previous period and the amount of rent incurred. Research by (Gibassier \& Alcouffe, 2018), their review how environmental management accounting (EMA) and controls (EMCS) are linked with sustainability. They are present six avenues for research to investigate further how EMA and EMCS can contribute to the missing link to sustainability. Environmental management accounting (EMA) is an innovative management accounting approach that covers a large range of tools with the purpose to support different actors in environmentally beneficial decision-making in companies (Schaltegger, 2018). Followed by the stage of presentation of costs associated with waste management that occur in BUMDes. It then ends with a stage of disclosure made by BUMDes regarding environmental costs incurred at the TPST unit.

The components recorded in the financial statements consist of:

1. Income Statement which is a financial statement that describes the elements of revenue and expenses of the company or how much income over a certain period and how much the cost is sacrificed company to produce a net profit or loss. The components contained in the income statement are generally sales, cost of goods sold, gross profit, sales expenses, administrative costs, income and other expenses, operating profit, financing costs, profit before tax, income tax, net income and profit per share.

2. Statement of Changes in Equity, intended to determine the progress of the company viewed from the right of ownership (capital) during one accounting period. Thus, the report of changes in equity (capital) ie reports prepared to determine changes in capital owned or to know the final capital at one period. The elements contained in the statement of changes in equity are the initial capital of the year and additional capital, profit and loss salodo, Prive (Owner taking for personal use).

3. A balance sheet is a part of a company's financial statements arranged systematically and chronologically about the assets of a company in a certain period (showing the company's financial position at a certain period). The balance sheet consists of three elements, namely: assets, liabilities, and capital.

4. Cash Flow Statement is a financial statement that describes the amount of cash that comes out and that comes in as a result of the activities of the company in other words is a cash flow consisting of inflows within the company and outflow cash flow of the company and how many balances per period. The company's cash flow consists of three parts: cash flow from operating activities, cash flow from investment activities, and cash flow from financing activities.

Notes to the Financial Statements include narrative explanations or details of the figures contained in the Budget Realization Report, Balance Sheet and Cash Flow Statement.

Table 1. Implementation of Green Accounting

\begin{tabular}{|c|c|c|c|c|}
\hline No & Data Type & Data Source & Percentage & Success Criteria \\
\hline \multirow[t]{2}{*}{1.} & Knowledge about simple & BUmdes manager In Group 1 & $85 \%$ & Success \\
\hline & financial entry & BUmdes manager In Group 2 & $83 \%$ & Success \\
\hline \multirow[t]{2}{*}{2.} & Skill of BUmdes & BUmdes manager In Group 1 & $89 \%$ & Success \\
\hline & $\begin{array}{l}\text { managers on } \\
\text { environment-based } \\
\text { Accounting }\end{array}$ & BUmdes manager In Group 2 & $89 \%$ & Success \\
\hline \multirow[t]{2}{*}{3.} & Implementation based & BUmdes manager In Group 1 & $90 \%$ & Success \\
\hline & $\begin{array}{l}\text { on knowledge and skills } \\
\text { about environment- } \\
\text { based Accounting in } \\
\text { doing business }\end{array}$ & BUmdes manager In Group 2 & $90 \%$ & Success \\
\hline
\end{tabular}


Source: data processing

Implementation of Social and Environmental Responsibility is usually listed in a report that can be reported separately or combined in the annual report. In general, information submitted to the public is only AMDAL and air pollution control, while other environmental management performance information in detail is only submitted to environmental agencies. So for people who want to know it must access themselves

\section{Conclusions}

Related to BUMDes regulation is Permendagri No.37 Year 2007 which requires BUMDes to be transparent in reporting all expenses incurred during operation, including environmental cost. The regulation also directly calls for an accountability report and as a means of evaluation for subsequent activities. With the application of environmental accounting in all operational activities in the BUMDes then directly oriented to the interests of $3 \mathrm{P}$ ie profit (profit), people (community) and the planet (environmental sustainability). Application of environmental accounting also aims to find out how much environmental costs incurred in managing the waste by using the accounting system so as to minimize the costs incurred, can control corporate responsibility in maintaining the environment around the company, and can create environmental cost report to be a management guideline in decision making.

The materials provided during the training and mentoring include: (1) the importance of bookkeeping and the benefits of its use in running the business; (2) how to prepare an environment-based financial report using applicable rules; (3) disclosure of Environmental Accounting as a form of accountability of CSR implementation. The results show that: $90 \%$ of the level of achievement that Bumdes managers have been able to apply environmental accounting properly.

In the community service program the application of environmental accounting in the village enterprise sector can already be implemented properly. The TPST unit within the Village BUMDes Tajun is processing organic waste to be used as compost for the welfare of the local people. Of course, waste waste in the form of non-organic waste that is not processed, such as glass, plastic, and other non-organic materials that require future handling. Good handling in the form of transportation for sale, or burned. Likewise, if burned, will emit the impact of pollution on the social environment and ultimately demand the company in this case BUMDes to issue a policy in overcome by reporting related to the effort to prevent environmental pollution, namely by applying environmental accounting.

\section{Refrence}

Agustia, D. (2010). Pelaporan Biaya Lingkungan Sebagai Alat Bantu Bagi Pengambilan Keputusan yang Berkaitan Dengan Pengelolaan Lingkungan. Jurnal Akuntansi: Akrual, 1(2), 80-100.

Aniela, Y. (2012). Peran Akuntansi Lingkungan Dalam Meningkatkan Kinerja Lingkungan Dan Kinerja Keuangan Perusahaan. Berkala Ilmiah Mahasiswa Akuntansi, 1(1).

Branco, M. C., \& Delgado, C. (2009). Research on social and environmental accounting in Southern European countries. Revista Española De Financiación Y Contabilidad, XXXVIII(144), 663-675.

Correa, C., \& Larrinaga, C. (2015). Engagement research in social and environmental accounting. Sustainability Accounting, Management and Policy Journal, 6(1), 5-28.

Ding, X. F. (2009). A Study of the Influences of Environmental Accounting and Environmental Protection to Financial Performance. National Taiwan Ocean University, Keelung City, Taiwan.

Elyafei, S. (2012). Penerapan Akuntansi Lingkungan di RSUD Tarakan Jakarta. Universitas Bina Nusantara.

European Commission. (2001). Promoting a European Framework for Corporate Social ResponsibilityGreen Paper. Brussels.

Gibassier, D., \& Alcouffe, S. (2018). Environmental Management Accounting: The Missing Link to Sustainability? Social and Environmental Accountability Journal, 38(1), 1-18. 
Grzebieluckas, C., \& Campos, L. M. de S. (2012). Environmental accounting and environmental costs: an analysis of the scientific production from 1996 to 2007. Produção, 22(2), 333-343.

Hidayatullah, S. M. (2015). Analisis Penerapan Akuntansi Lingkungan Untuk Mengetahui Proses Pengelolaan Limbah dan Tanggung Jawab Sosial Pada Rumah Sakit IBNU Sina Kota Gresik. Universitas Islam Negeri Maulana Malik Ibrahim Malang.

Lindrianasari. (2007). Hubungan antara Kinerja Lingkungan dan Kualitas Pengungkapan Lingkungan dengan Kinerja Ekonomi Perusahaan di Indonesia. Jurnal Akuntansi \& Auditing Indonesia, 11(2), 159-172.

Mathews, M. R. (1997). Twenty-five years of social and environmental accounting research. Is there a silver jubilee to celebrate? Accounting, Auditing \& Accountability Journal, 10(4), 481-531.

Negash, M. (2009). IFRS and Environmental Accounting. Available at: Https://Papers.Ssrn.Com/Sol3/Papers.Cfm?Abstract_id=1516837, 1-34.

Nilasari, F. (2014). Analisis Penerapan Akuntansi Lingkungan Terhadap Pengelolaan Limbah (PG Djatiroto). Artikel Ilmiah Mahasiwa, 1-7.

Olatunji, T. E. (2017). Environmental accounting: A tool for conserving biodiversity in tropical forests. Journal of Accounting and Taxation, 9(9), 109-118.

Owen, D. (2008). Chronicles of wasted time? A personal refl ection on the current state of, and future prospects for, social and environmental accounting research. Accounting, Auditing and Accountability Journal, 21(2), 240-267.

Roozenburg, N. F. ., \& Eekels, J. (1995). Product Design: Fundamentals and Methods. John Wiley \& Sons Ltd.: Hoboken, NJ, USA.

Schaltegger, S. (2018). Linking Environmental Management Accounting: A Reflection on (Missing) Links to Sustainability and Planetary Boundaries. Social and Environmental Accountability Journal, 38(1), 19-29.

Seetharaman, A., Ismail, M., \& Saravanan, A. S. (2007). Environmental Accounting as a Tool for Environmental Management System. J. Appl. Sci. Environ. Manage, 11(2), 137-145. https://doi.org/10.4314/jasem.v11i2.55013

Suaryana, A. (2011). Implementasi Akuntansi Sosial dan Lingkungan di Indonesia. Jurnal Ilmiah Akuntansi Dan Bisnis, 6(1), 1-26.

Tu, J.-C., \& Huang, H.-S. (2015). Analysis on the Relationship between Green Accounting and Green Design for Enterprises. Sustainability, 7, 6264-6277.

Yakhou, M., \& Dorweiler, V. P. (2004). Environmental accounting: an essential component of business strategy. Business Strategy and the Environment, 13(2), 65. 